\title{
Transatlantica
}

Revue d'études américaines. American Studies Journal

$2 \mid 2017$

(Hi)stories of American Women: Writings and Rewritings / Call and Answer: Dialoguing the American West in France

\section{François Brunet (ed.), Circulation}

\section{Richard Phelan}

\section{(2) OpenEdition}

\section{Journals}

Electronic version

URL: https://journals.openedition.org/transatlantica/10473

DOI: $10.4000 /$ transatlantica. 10473

ISSN: $1765-2766$

Publisher

Association française d'Etudes Américaines (AFEA)

Electronic reference

Richard Phelan, "François Brunet (ed.), Circulation", Transatlantica [Online], 2 | 2017, Online since 19 April 2019, connection on 02 February 2023. URL: http://journals.openedition.org/transatlantica/ 10473 ; DOI: https://doi.org/10.4000/transatlantica.10473

This text was automatically generated on 2 February 2023.

\section{(c) $(1) \Theta($}

Creative Commons - Attribution-NonCommercial-NoDerivatives 4.0 International - CC BY-NC-ND 4.0 https://creativecommons.org/licenses/by-nc-nd/4.0/ 


\title{
François Brunet (ed.), Circulation
}

\author{
Richard Phelan
}

\section{REFERENCES}

François Brunet (ed.), Circulation, Terra Foundation Essays, Chicago, University of Chicago Press, 2017, 224 pages, 58 color plates, 24.95 \$, ISBN 9780932171-61-0 90000.

1 Circulation is firstly the physical movement of artworks, a matter which has since the beginning been the precinct of art historians, but has gained new forms of scholarship in recent times (in the work of Jennifer Roberts for example). The reproduction and distribution of images as well as the evolution of the requisite technology is of course central. Yet, the term circulation refers as much to the discursive fortune as to the material fortune of artworks and so the field of visual studies devotes itself to mapping journeys between places and times of production, of exhibition, and of validation and revalidation. Circulation also involves creative processes of "refiguration" from work to work, from artist to artist and from one cultural tradition to another (Panofsky speaks of this as "pseudomorphosis"), processes which image scholars such as W.J.T. Mitchell continue to trace with detail and delight. Reconfigurations can occur between heterogeneous media and such "remediation," as identified by Bolter and Grusin, has been the topic of recent intermedial investigations. In the last fifteen years, moreover, accelerated or "viral" circulation has of course brought the attention of researchers to the phenomenon of "iconization." Ultimately, then, circulation concerns the ways in which a culture or a number of interacting cultures use an artwork.

2 The question then is broad; as François Brunet himself warns, it is almost co-extensive with the term history. The volume he has edited addresses the notion with great precision of focus and brings to the conversation a compelling set of new studies. The fields covered by the six essays range from painting, engraving, photography, photojournalism, film, to magazine, brochure and book design. The material examined starts with revolutionary America and ends with contemporary culture. The dialogues are transatlantic, with a special bias towards French-American exchanges. 
3 The introductory essay by Brunet (1960-2018), a former fellow of the Institut Universitaire de France and professor at Université Paris Diderot, is a complex elaboration on the notion of circulation. The challenge, he admits, is to think the question of circulation within "the succession of historical situations" (14) of American art, but outside the frame of today's digital culture and "its fantasies of total and immediate circulation" (13). "How" he asks, "have pictures and objects-in different periods-acquired meaning, worth, agency, form, even aesthetic status, by moving, or more generally by gaining 'currency' [...]?" (13). The debate on the "Americanness of American art" is usefully referenced and a dialogue is constructed with clement Greenberg whose theory of modernism eschewing circulation (associating the latter with kitsch) seems in this context to be oddly defective. Brunet also engages with the work of Jennifer Roberts, pointing to what he sees as a possible paradox of her studies of portability and material history: if works such as Copley's Boy with a Flying Squirrel indeed bear their transport as an inscription in their visual form, does this not reduce the importance of their real trajectories? The critical debate is pursued with Appadurai, Greenblatt, Miller, Mirzoeff, and Rancière. The corpus that this first essay goes on to examine in particular is from the nineteenth-century photographic surveys of the American West, works which begin as scientific archives with a cultural destination and end up with something of the status of art.

4 The study of "How Silhouettes Became 'Black" by German researcher Frank Mehring traces the genealogy of a practice which in late-eighteenth-century Europe was used to represent upper-class white bourgeois selfhood and which has since the Harlem Renaissance in the USA and the recent work of Kara Walker become associated with African-American cultural identity. Mehring's concluding paragraphs study the early twenty-first century use of silhouettes in advertising campaigns for popular music which play with a transnational fantasy of "becoming black" in order to see oneself as a rebel capable of performing energetic self-expression.

5 The narrative convokes the mythical silhouette artist mythologized by Pliny The Elder as the very origin of painting, as well as the use of silhouettes on ancient Greek vases. It then charts the movement from the pseudoscience of physiognomy in Northern Europe to the mania for silhouettes that reached the United States in the 1830s, a visual media revolution predating that of photography. Woodcut novels are the missing link that the author puts back into the twentieth-century story of this "intermedial" circulation. For, indeed, in the 1920s silhouettes underwent a remarkable transformation and were used by the "New Negro" movement to "open up new perspectives on African American music, literature, theater and dance" (192). Mehring weaves into this part of the story the figure of German-born artist Winold Reiss who became an influential and innovative collaborator of Allan Locke as well as the mentor ("intercultural mediator and teacher," 196) of Aaron Douglass. Reiss contributed to publisher Alfred Knopf's strategy of giving African American literature a modernist visual specificity. Reiss also incorporated Mexican elements into his work; this hybridity transcending national and racial codes was further enhanced by the contribution to the Harlem Renaissance of Mexican caricaturist Miguel Covarrubias.

6 Douglass was to appropriate the silhouette designs of Winold Reiss in his project to counter stereotypical images of African American with "the very visual genre that is prone to stereotyping because of its radical omission of detail: silhouettes" (192). As Kara Walker argued later: "The silhouette says a lot with very little information, but 
that's also what the stereotype does" (208). Douglass adds a new dimension to the practice by literally layering his Egyptian-style drawings and paintings with the shadows of historic slavery and of contemporary lynching. Mehring points out for instance the way Douglass perturbs his elegant depiction of joyful nightlife with uncanny contours appropriated from German Expressionist films.

The circulation in question here is carefully established, the dialogue in the footnotes stimulating. That is also the case of another essay devoted to the way American pictures were transformed into American art by being circulated outside their explicitly intended audiences: Tom Gunning's study of the French reception of early American cinema. "Did The French Invent American Cinema?" asks the Chicago-based author. The opening section examines with relish the details of the rivalry between French and American film companies in the early twentieth century. The second part argues that France invented American cinema when it stopped being an exporter of films to the United States and became an importer of American movies. This reception was far from passive, as "already by the twenties French critics discussed American films with a seriousness surpassing their reception in their native land" (157). Film culture in France, in other words, redefined American cinema discursively. In a story less well-known than that of the French new wave reception of American cinema or of Andre Bazin's seminal essays in the 1950s, we read of Louis Delluc's and Jean Epstein's theorizations of photogénie, of the film invention of a syntax of face and landscape, and of the unexpected aspects of beauty that appealed to Surrealist poet Philippe Soupault. Long before Godard's trans-medial celebration and investigation of the History of the Cinema, critics and artists working in French moved Americans to see and study what was valuable in their cinema.

For every image object or archive that circulates, Brunet suggests, there are others that do not. Such uncirculated images, which J. M. Mancini, of the Department of History at Maynooth University in Ireland, encourages us to think of as the dark matter of American art, can tell us as much about the past as the images we can see. Mancini proceeds to exemplify and embody Brunet's contention by an investigation into the lack of circulation of a French document on the American Revolution. The Collection of Engravings published by Nicolas Ponce and François Godefroy in Paris between 1783 and 1784 places emphasis on the revolution as an inter-imperial war between Britain, France and Spain. Hence the places represented, unlike those of Cabot Lodge's history (1898) of the American Revolution, are not chiefly in Massachusetts but in the Dominican Republic, Senegal, and Pensacola in West Florida. What is prioritized is the war's global aspect. That this set of engravings did not prevail, that its images were not taken up and repeated is evidence that the reading of the American War of Independence had become almost exclusively, like the meaning of Paul Revere's Bloody Massacre, an "anticolonial struggle against a monarchical master whose soldiers fired into the Boston crowd" (46). What was not shown, what was suppressed in the $19^{\text {th }}$ century, with respect to Spain particularly, as argued by Mancini, was the image of the USA as empire. What was unmade in the history of the revolution was the visualization of the tar bucket and the scaffold in favor of the violence of iconoclasm in the beheading of statues of King George. Histories of "uncirculation" (as Mancini puts it) are difficult to tell, but the author raises masterfully to the theoretical challenge charted in his introduction by François Brunet: to ask and point out to what extent 
"non-circulations, absences, invisibilities, negations and destructions" (37) have been determining factors in the history of American art.

"Shifting Images" by Thierry Gervais of Toronto outlines a history of American news photography between the Civil War and World War II. Focusing on the very early development of photojournalism, it describes, with regard for instance to the SpanishAmerican war of 1898 and the Russo-Japanese war of 1904, the movement of images between different media, and the ways in which "processing and reprocessing photographs transform them into artificial, artful and artistic pictures" (34). The approach of the Second World War saw a transfer of European skills to the illustrated press in New York and hence led to the emergence in 1936 of the "photographic essay" in Life, where the photographs provided not an objective window, but a subjective point of view, and were composed by the managing editor of the magazine. The essay's precise description reveals the layers of circulation between different publications, between different countries as well as between different professional agents in the news and image culture.

10 At the center of the volume is a case study by Helene Valance (Universite de FrancheComté) devoted to Whistler's Mother, and to its trajectory from 1871 to the present. The construction through time of the cosmopolitan artist's aesthetic Arrangement in Gray and Black $N^{\circ} 1$ as an American icon, whose original was painted in England and bought twenty years later by the French government, is paradoxical, to say the least, and richly problematic. It thus "exemplifies many aspects of circulation as it has moved with extreme flexibility across time and geographic borders but also sociocultural categories and medias, acquiring new meanings through these multiple transfers" (120). Valance delicately unfolds these meanings and deftly maps these transfers.

11 Central to Whistler's project and to the promotion of his painting was his reputation: purchase by a French museum was therefore the best means for Portrait of the Artist's Mother to circulate in America. By the end of the century, the painting had served as model for works by other American artists and had begun in the early $20^{\text {th }}$ century to appear in magazines on Mother's Day, framed, as World War I approached, in patriotic rhetoric. The painting itself toured the USA in the early 1930s, a physical circulation organized by Alfred Barr and the MoMA. It would soon feature next to Mona Lisa (and Mickey Mouse) as a line in a song by Cole Porter. In 1934, it was converted into a stamp dedicated by FDR himself to the "Mothers of America." It was now, in the fullest sense, an icon: calling to "collective adhesion at a moment of national crisis" (128). Valance explores the history of the picture's reception, unveiling both Whistler's own ambivalent attitude and what was constantly read as the work's central paradox: its "ability to raise sentimental associations of motherhood and to negate them" (as Jonathan Weinberg termed it in 2001). The spare formalism of the painting would be reinvested as Puritan restraint and moral sobriety, its "emptiness" would serve as a template for projection. "Can there be a circulation without misrepresentation?" (139) is the concluding question of this witty essay, which puts a spin on Brunet's introductory-essay-title-statement, "No Representation without Circulation."

12 Third in a series of Terra Foundation essays aimed at outlining key concepts in American art, Circulation is scrupulously researched, impeccably edited, and beautifully produced. It offers sharply outlined and differentiated models for further research and debate. Great scholarship, let us not forget, is an indispensable part of the circulation of images. That of François Brunet will remain a model. 
INDEX

Subjects: Recensions

\section{AUTHORS}

RICHARD PHELAN

Aix-Marseille Université 